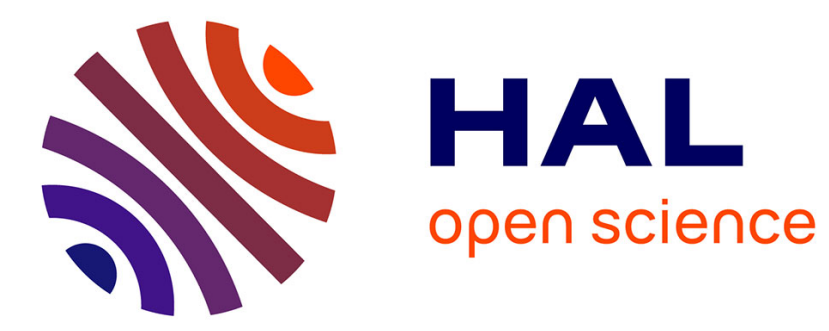

\title{
When the arts inspire businesses: Museums as a heritage redefinition tool of brands
}

Damien Chaney, Mathilde Pulh, Rémi Mencarelli

\section{To cite this version:}

Damien Chaney, Mathilde Pulh, Rémi Mencarelli. When the arts inspire businesses: Museums as a heritage redefinition tool of brands. Journal of Business Research, 2018, 85 (452-458), 10.1016/j.jbusres.2017.10.023 . hal-01698405

\section{HAL Id: hal-01698405 \\ https://hal.univ-smb.fr/hal-01698405}

Submitted on 1 Feb 2018

HAL is a multi-disciplinary open access archive for the deposit and dissemination of scientific research documents, whether they are published or not. The documents may come from teaching and research institutions in France or abroad, or from public or private research centers.
L'archive ouverte pluridisciplinaire HAL, est destinée au dépôt et à la diffusion de documents scientifiques de niveau recherche, publiés ou non, émanant des établissements d'enseignement et de recherche français ou étrangers, des laboratoires publics ou privés. 


$\begin{array}{lll}\text { Damien Chaney } & \text { Mathilde Pulh } & \text { Rémi Mencarelli } \\ \text { Laboratoire Regard EA 6292 } & \text { Université de Bourgogne } & \text { Professeur des Universités } \\ \text { Groupe ESC Troyes } & & \text { IAE Savoie Mont Blanc } \\ & \text { Université Savoie Mont } \\ & \text { Blanc }\end{array}$

IREGE - E.A. 2426

\title{
When the arts inspire businesses: Museums as a heritage redefinition tool
}

\section{of brands}

\begin{abstract}
While the literature has mainly considered brand museums as communication tools or complex retail environments, this article analyses them through a heritage framework and suggests that brands can use heritage technologies of the arts for their own purposes. The case study of the brand museum of the Laughing Cow highlights the heritage technologies the brand uses to endorse two heritage roles: an inter-generational memory role based on the transmission of the brand's history and a community representation role through spaces and objects. As a consequence, this research sheds light on how brands can come to be accepted as heritage objects. By using heritage technologies within a museum, brands can capture heritage functions, and thus no longer fully rests in a market logic: the brand becomes a sacred and inalienable common good.
\end{abstract}

Keywords: brand museum; heritage; brands; memory; transmission; flagship stores 


\section{Introduction}

The world of business provides inspiration for many cultural organizations. In the museum sector, the proliferation of shops, restaurants, and bars; the development of brands; and the increasing use of private sources of funding (sponsorship, endowment) illustrate this commodification trend of the arts. Though often criticized as a form of perversion (Adorno \& Horkheimer, 2007), the current place of arts in society cannot be assessed simply by looking at its shift towards the world of business and without taking into account the extent to which the world of business uses the arts in the opposite direction (Meisiek \& Barry, 2014; Schiuma, 2011).

Analysis of the trend of the artification of goods is important for several reasons. As Medoff Kara Barnett, executive director of the Lincoln Center for the Performing Arts (New York), notes, the "pollination of ideas” moves not only from the market to the arts but also from the arts to the market (http://www.c2montreal.com/speaker/kara-medoff-barnett/). Many examples illustrate this phenomenon—famous architects who design outlet malls (David Chipperfield for Valentino, Rem Koolhaas for Galeries Lafayette), capsule collections created by artists (Karl Lagerfeld and H\&M, Takashi Murakami and Vans), and temporary exhibitions hosted within (flagship) stores, thus turning them into art galleries (UNIQLO flagship store in New York). Companies increasingly integrate creative and artistic dimensions into their strategies to find new sources of value in an increasing context of trivialization of the commercial offer (Brellochs \& Schrat, 2005).

One of the most visible signs of this artistic aspiration of companies is the proliferation of brand museums in many different sectors, as illustrated by the recent opening of the Aéroscopia museum by Airbus (France) and the future museums of Audemars Piguet (Switzerland), Nestlé (Switzerland), and IKEA (Sweden). The brand museum represents a “corporate facility with tangible objects and/or exhibits, displayed in a museum-like setting, 
that communicates the history, operations, and/or interests of a company to employees, guests, customers, and/or the public” (Danilov, 1992, p. 4). Brand museums are born from the alliance of two apparently dissonant entities (Byrom \& Lehman, 2009) and thus constitute a promising field to examine the cross-fertilization of arts and management; and between culture and brands (Meisieck \& Barry, 2014; Schiuma, 2011).

However, the literature largely considers brand museums from a praxeological perspective and treats them as communication tools (Nissley \& Casey, 2002) or complex retail environments (Hollenbeck, Peters, \& Zinkhan, 2008). But in exhibiting their brands in a museum, companies go beyond a purely commercial relationship with their customers to redefine their brands as heritage artifacts (Smith, 2006). Nevertheless, the museum orientation of brands remains poorly studied in the literature and thus raises several questions: (1) How can brands redefine themselves as heritage artifacts, such as collections of art objects? (2) Do visitors consider this registration of the brand in the heritage corpus legitimate? and (3) what are the consequences of brand museums for the brand?

To answer these questions, this article develops a heritage framework to analyze the heritage process at work in brand museums and the consequences for the brand. The article begins by explaining the contributions of the heritage interpretative framework to the existing literature. Then, a case study of the museum the Laughing Cow (industrial cheese brand) highlights the roles endorsed by the brand through the heritage process and identifies the museum techniques used to legitimate this registration in the heritage corpus. The study concludes with a general discussion of the findings, limitations, and avenues for further research.

\section{Analyzing brand museums through a heritage framework}


Though largely a research concern in the social sciences (Rodner \& Preece, 2015; Schroeder, 2006), the relationship between art and business also appears in management and marketing (Joy, Wang, Chan, Sherry, \& Cui, 2014; Meisiek \& Barry, 2014). However, as Schiuma (2011, p. 1) argues, “in today’s complex business landscape, as organizations are challenged by new and increasingly complex problems, the arts provide a new 'territory' to inspire executives ... to see their organizations differently.” However, little is still known about how firms become involved in artistic activities and endorse the role of cultural agent (Chong, 2013).

\subsection{Brand museums: From a praxeological to a heritage perspective}

Some studies in management and marketing do examine brand museums. In particular, the management literature focuses on brand museums as spaces embodying organizational memory and suggests that organizations can use corporate museums strategically to improve their image (Burghausen \& Balmer, 2014; Nissley \& Casey, 2002). Through the sociological theory of the re-enchantment of consumption (Ritzer, 2005; Thompson, 2006), marketing studies consider brand museums complex retailing environments that mix entertainment and brand experiences (Hollenbeck et al., 2008; Kozinets, Sherry, DeBerry-Spence, Duhachek, Nuttavuthisit, \& Storm, 2002). These studies are relevant for understanding the characteristics of organizational memory and its impact on corporate image (management perspective) and for identifying the structuration of a brand experience and its effects on consumers (marketing perspective). The findings suggest the praxeological goals of brand museums by exposing their external communication function (to demonstrate the quality and know-how of the brand), internal communication function (to create a social link between employees), and additional channel function through gift shops. 
Although museum spaces have praxeological functions, the current argument differs from those discussed previously. Indeed, according to the International Council of Museums, the mission of a museum is to "acquire, conserve, research, communicate and exhibit the tangible and intangible heritage of humanity and its environment for the purposes of education, study and enjoyment” (http://icom.museum/the-vision/museum-definition). We argue that the praxeological function conceals a heritage function because of the process at work within the brand in museums. As Hollenbeck et al. (2008) note, brand museums integrate specific characteristics of museums (e.g., collection and exhibition of objects, specific displays, importance of educational aims). However, the heritage process that causes organizations and/or brands to move away from strategic and/or retailing objectives appears only tangentially in prior studies (Rose, Merchant, Orth, \& Horstmann, 2016). Thus, we propose to analyze these "third spaces" (Oldenburg, 2001) through a heritage framework. By introducing this new theoretical perspective, this study offers insights into the consequences of brands’ quest for artistic legitimacy.

\subsection{The legitimacy of the brand in the heritage corpus}

To investigate brand museums through a heritage framework, we must define the notion of heritage to understand the legitimacy of introducing a brand in the heritage corpus. Lowenthal (1998) defines "heritage” as a legacy that society or social groups have created. The collective dimension of the definition is central because heritage creates social relationships within a group or a territory (Dicks, 2000). Heritage also represents a social construction that gives to a specific good the value of moving from the private to the public and collective spheres (Smith, 2006). The heritage process thus corresponds to the transformation of an object in a symbolic doppelgänger through a set of collectively accepted values (Smith, 2006). 
The heritage process tends to spark much research enthusiasm, leading some scholars to describe the phenomenon as "heritage crusade" or "heritage inflation” (Heinich, 2009; Lowenthal, 1998). The continuous development of heritage can be explained by a fear of oblivion, which imposes on the society a duty of memory (Davison, 2005). Heritage also allows for the transmission of sacredness in the renewed symbolic system of disenchanted modern societies (Gauchet, 2005).

The extension of the heritage corpus paves the way for an ordinary heritage—as opposed to an extraordinary heritage—-for objects or places at the heart of groups' social identity construction (Grimwade \& Carter, 2000). That is, a heritage rupture occurs in which the ‘time of monuments' gives way to a ‘heritage time' of everyday objects (Cleere, 2001). Thus, the heritage process practiced by official experts (arts institutions) leaves room for a heritage practiced by non-specialists (companies) searching to take over the values of an institutional heritage.

By creating museums dedicated to their brands, companies can assume the role of nonspecialists artistic entrepreneurs and fully illustrate the phenomenon of ordinary heritage. Companies thus use, appropriate and accommodate what Rowland and De Jong (2007) calls technologies of heritage, i.e. techniques and vocabulary used by heritage official experts. For companies, the willingness to register their brands at the heart of heritage ideology captured through museums reflects an institutional means to belong to the art world present in contemporary societies (Becker, 1982). Indeed, this process of museumification transforms the brand into "an idealized re-presentation of itself, wherein everything is considered not for its use but for its value as a potential museum artifact” (Di Giovine 2008, p. 261).

The brand here assumes a cultural role and tries to expand beyond its original commercial world by associating itself with heritage functions, thus adding new symbolic meaning. However, the process by which the brand re-defines itself as a heritage artifact, such 
as a collection of art objects (Lowenthal, 1998), remains largely under-researched. With the circulation of the brand between the business world and the museum, understanding the role of the brand in this heritage process and the technologies from the museum world used to create a heritage artifact is important.

\section{Method}

\subsection{Research site}

The goal of this research is to understand the cultural orientation of brand museums, considered here as third places, through a heritage framework. To achieve this goal, we conducted an extended case study by analyzing the brand museum dedicated to the Laughing Cow located in France. The Laughing Cow is a cheese brand created in 1921 by the Bel Group (which had revenues of $€ 2.8$ billion in 2014). The Laughing Cow was originally created in Jura, a small French region close to Switzerland, but is now an international brand (present in 136 countries) due to industrial development and an original marketing strategy. In 2009, the Bel Group opened its brand museum in Lons-le-Saunier (Jura, France), a 27,000square-foot museum called the Laughing Cow House. "More than just a company museum, the Group has sought to remake the site in the Laughing Cow's image, where visitors rediscover the values of conviviality, humor, and innovation that characterize the brand.” In the Laughing Cow House, the public can rediscover through a ludic tour "collectibles, images, documentation... which constitute the heritage of the brand and its multiple representations" (http://www.lamaisondelavachequirit.com/fileadmin/Presse/MVQR-DP_4.pdf). Conceived as a "living and amazing place," the objective of the museum is to create an "emotional relationship between the brand and its visitors” (museum manager). The Laughing Cow serves as the case study herein because of its membership in the food industry, in which significant enthusiasm for brand museums exists largely due to the strong relationship among 
food, cultural identity, and heritage (Tellström, Gustafsson, \& Mossberg, 2006). In addition, in contrast with luxury brands (Dion \& Arnould, 2011), the Laughing Cow is an industrial foil-wrapped, spreadable, triangular cheese used daily and with no intrinsic artistic quality.

\subsection{Data collection and analysis}

We conducted an extended case study to understand the heritage process at work in brand museums. Extended case studies offer the opportunity to obtain in-depth understanding of a contemporary phenomenon within a real-life context (Yin, 2013). We investigated the heritage process in brand museums by collecting data from multiple sources to avoid fragmented realities (Arnould \& Wallendorf, 1994). We collected data in several stages over a two-year period (2012-2013) and triangulated the data to strengthen the validity of the findings.

The first and introductory stage involved examining commercial and communication documents from the company (pamphlets, museum map, websites, press releases). These documents illuminate how the Laughing Cow House introduces the brand experience to visitors. An interview with the manager of the museum complemented these secondary data. The face-to-face semi-structured interview centered on the museum’s origin, its implementation, and the objectives of the museum for both the Laughing Cow and the Bel Group. The interview lasted approximately 45 minutes and was recorded and fully transcribed.

In the second stage, ethnographic techniques served to collect facts and actions in real situations to better understand the brand museum in its context (Arnould \& Wallendorf, 1994). We conducted six sessions of participant observation, alone or in groups, spread over the two years of data collection. During successive visits, we took many notes and pictures in 
order to write narratives in an introspective reflection process (Takhar-Lail \& Chitakunye, 2015).

In the third stage, we collected narratives from consumers after their visit and guided introspections (Wallendorf \& Brucks, 1993). We instructed participants to take pictures during their visit and, if necessary, to describe them in a notebook. Thus, after their visit, the participants were able to write an experience narrative. This methodological choice gives participants the opportunity to live the experience as freely as possible and to proceed $a$ posteriori to a factual and introspective plan. We collected 23 narratives, constituting a 124page corpus, with an average of more than five pages per narrative. Only first-time visitors were involved in this stage, so that all are in the same discovery process of the museum, regardless of their prior knowledge of the brand. Table 1 provides informant demographics. Because food is closely related to the notion of “territoriality" (Wilson, 2006), we included the region of first-time visitors to obtain various perceptions of the Laughing Cow. Of the 23 informants, only one resided in the same region as the Laughing Cow House.

[Insert Table 1 about here]

We analyzed the data jointly and without researcher distinction in a systematically comparative and hermeneutical process (Spiggle, 1994; Thompson, 1997). We manually coded the data to identify themes related to the research questions. With an abductive perspective, we mobilized the conceptual framework around the concept of heritage and the process for introducing an artifact within the heritage corpus. This conceptual framework helped us identify the different technologies associated with the Laughing Cow House's heritage building and the roles of the brand in the museum. Furthermore, the coding process entailed alternating individual interpretation and pooling phases with the aim to reach a shared understanding of the phenomenon and a progressive abstraction that neutralized individual subjectivities (Goulding, 2005). The identification of dissonant characteristics led 
us to systematically reformulate the conclusions, without necessarily seeking convergence. Finally, the triangulation of the data and successive iterations during the analysis enabled us to maintain an analytical distance to the field (Gould, 2006).

\section{Results}

Analysis of the Laughing Cow House shows that the brand endorses two roles through this heritage construction: an inter-generational memory role and a community representation role.

\subsection{The inter-generational memory role}

To become a heritage object, the brand assumes an inter-generational memory role. As Philippe, the director of the Laughing Cow House, noted, "five generations have contributed to the success of this brand ... which is a real [Marcel] Proust madeleine for all visitors.” In addition, the museum strives "to bring together the children of today and those of yesterday to allow them to meet” and “invites [sharing] and exchange between generations” (http://www.lamaisondelavachequirit.com). This inter-generational link materializes through the desire "to convey the brand's memory to a wider public.” Thus, the preservation and exhibition of artifacts allows the brand museum to present itself as a collective memory intended to be passed on to future generations (Nissley \& Casey, 2002).

First, the brand transmits its history by highlighting its age throughout the visit; specifically, the museum provides dates on all devices, which facilitates visitors' awareness of the historical character of the brand (Lowenthal, 1998). Dating the different objects helps the brand meet the history requirement of the concept of heritage (Riegl, 1903). Thus, the Laughing Cow House associates the brand with specific events through dating practices that involve the company, its founders, and its products. Visitors Florine and Pascal noted that they were surprised "to learn [that the company] was created here in Lons-Le-Saunier on 
April 16, 1921, by Leon Bel under the name of Gruyère cream” and that they appreciated that “the explanatory panels all contain dates, which are important to have some landmarks.” The reference to dated origins as valued by visitors is exemplified by Marine, who stated that she was surprised by the "richness of the history of this brand which is very old."

The transmission of history through dating is nevertheless limited only to positive aspects (Brown, Kozinets, \& Sherry, 2003). Using this normative vision of the past, the museum highlights only the achievements and successes of the brand (Goulding, 2000). Thus, the Laughing Cow illustrates its “fine example of industrial success” (Philippe, manager): “The first recipe developed by Bel has been rewarded in several agricultural competitions ... to such an extent that only five years after its creation, Léon Bel [was able to open] a bigger factory.” Most of the events associated with the brand highlight its "tremendous" or “exceptional” successes (http://www.lamaisondelavachequirit.com). Léon Bel, the founder of the brand, is glorified and presented as a "cheerful and friendly man” who engaged in "a bold and risky venture" by launching processed cheese that he had the "brilliant idea to rename ... with a very original name: The Laughing Cow" (http://www.lamaisondelavachequirit.com). Even less positive facts, such as the large number of counterfeits, are presented as a tribute paid by competitors to the brand and, thus, as an indicator of success: "Is the success of a brand not measured by the number of its unwanted tributes?” (http://www.lamaisondelavachequirit.com).

Telling a great story also helps build relationships between the brand's history and those of visitors and enables visitors to evoke their own memories to generate nostalgic feelings. For example, this emotion is present in Caroline’s narrative: “I am discovering again a part of my childhood with all the objects and signs that I used to see when I was young.... It's touching to see those pictures and realize that I grew up with this brand.” 
Second, the brand aims to communicate its expertise. As Philippe (manager) stated, “when people enjoy this brand, they want to know more about it.... People ask many questions about the different products they like." The museum thus provides material and technical evidence of its expertise. To demonstrate its know-how, the museum offers a reconstruction of the manufacturing process through guides and videos (which are substitutes for the real observation of the production process). As Pascal explained after his visit, "I am really surprised to learn that the Laughing Cow is made of Gouda, Cheddar, Emmental, dried milk, milk proteins, butter and melting salts (to make sure that all products can be mixed). After seeing the machines, I understand even better, with the video explaining very well the process of manufacturing and packaging.” Aurélie also noted her appreciation of this transmission of know-how, stating that she "learned a lot about the production of this cheese" during her visit.

Third, the brand museum transmits anecdotes, folktales, and stories about the brand. In particular, this transmission comes from narratives or quasi-narratives (Holt, 2004; McCracken, 2005); that is, the brand highlights stories since its creation (Eliade, 1954) and no longer simply describes and conveys its historical reality and traditional know-how. The Laughing Cow House presents itself as a space that offers a "trip [to get] at the heart of the secrets of the Laughing Cow" (http: //www.lamaisondelavachequirit.com), to help visitors discover the "magic recipe of this brand” (Philippe, manager). Thus, many stories are communicated to feed the legend of the origins of the brand. For example, Chloé noted that she was "glad to hear a story about the origin of the name [Laughing Cow] which is supposed to come from the term 'wachkyrie' derived from the German work 'Valkyrie'.” This narrative technique helps the brand museum move away from a scientific and historical expertise to a more magical and wonderful orientation. 
The company creates this narrative technology to connect the brand with timelessness. The museum presents not only the history of the brand but also the past of the brand in conjunction with its present and future. Philippe (manager) stresses that the Laughing Cow House is "not only a place where memory of the past unfolds.... It also opens the present and even to the future of the brand.” The museum aims to "stage the Laughing Cow throughout the ages, from the Las'Cow to the Space'Cow” (http://www.lamaisondelavachequirit.com). In contrast with a historical time, this narrative technology transcends visitors' time references and presents the brand as an eternal legend, outside time (Holt, 2004). The Laughing Cow House thus constitutes “a place to celebrate ancestors..., a place of memory to indicate how it was before and also what it has become today” (Philippe, manager). Henry, another visitor, noted that the Laughing Cow "is part of the French icons that have been able to withstand the test of time.” This registration of the brand non-chronologically seems to contradict the dating process but also allows the brand to extend beyond everyday life. This technology gives the brand an immutable character, thus facilitating its entry into the heritage register because the brand now represents an ancient artifact — the brand is no longer treated as an ordinary object subject to the deterioration of time (Lowenthal, 1998).

\subsection{The community representation role}

By becoming a heritage object, the brand also endorses a role of community representation. Similar to national heritage that symbolically represents a nation, the construction of heritage allows the brand to be part of a community—-to represent and embody the community and thus to value its main identity features. According to Philippe (manager), the company chose to set up the museum in Lons-le-Saunier to show that the Bel Group "has not forgotten the territory of the Jura" and that the connection between the brand

\footnotetext{
${ }^{1}$ Las'Cow and Space'Cow are word games that play on the contraction of the words "cow" and "Lascaux" (in reference to Lascaux Caves, a complex of caves in France famous for their Paleolithic cave paintings) on one side and "cow" and "spaceman" on the other.
} 
and its homeland is evoked throughout visits because the Laughing Cow "remains a child of the Jura” and is also "a huge success of the 'Made in France' [label],” thus embodying both a local and a national community.

To realize this community representation role, the brand museum exhibits visible traces of the community's activity in the area. In this way, the brand endorses a role of preservation of the culture. The brand museum communicates the truth of the heritage artifact to visitors by revealing the link between the object and its origin (Grayson \& Martinec, 2004). The Laughing Cow House demonstrates the authenticity of the exhibition, thus legitimizing the role of the brand as a cultural entrepreneur able to preserve the culture of the community. Authenticity is based first on the place chosen to host the museum because of its connection with the origin of the brand. The manager noted that the Laughing Cow House is "built on the first manufacturing site of the Laughing Cow. And there is real value to be placed not only in Lons-le-Saunier but also at this specific crossroad." This location is the actual "birthplace of the famous processed cheese" (http://www.lamaisondelavachequirit.com). The authenticity of the place is also visible in some exhibition spaces, such as in the first room, where the audience enters "in the original cellar where the products were made" (Laura, visitor). These places appear “unique” or “original, ancestral” for visitors, as both Florine and Anne-Lucie explained. Authenticity is also based on the "raw" nature of the objects that bear the marks of time and of their prior use. The museum exhibits commercial documents in their original condition and many tools originally used to manufacture products. Visitors also appreciate seeing “objects for real” (Caroline), such as "boxes of the famous brand, and everything about the evolution of its logo or about its communication campaigns” (Aurore), and discovering “real production machines” (Anne-Lucie). The use of the historic site of production and the display of original objects expose the physical traces related to the production activity. This 
authenticity makes the objects unique and credible in biographical, cultural, and historical terms (Benjamin, 1968).

To further support the authenticity of the place, the brand museum also uses simulations (Eco, 1986): soft lighting, smells (wood), and artificial objects (false wheels of cheese, reproduction of old groceries, and imitations of cow hooves on the ground). However, these dummy items can ultimately disrupt visitors' notion of the place and make them doubt the real authenticity of the artifacts and the place. During their visit to the Laughing Cow House, some visitors, such as Anne-Lucie, stated that they felt like they were "in a reconstituted demonstration cellar that looks nothing like a vintage wine cellar” because of the "artificial wheels put on the shelves and [of] the renovation [which] seems to have removed the authenticity of the place.” This inauthenticity extends to the gift shop, where some visitors were "surprised by the many 'made in China’ products” (Fanette). Many visitors perceived these objects as not aligned with the territorial proximity expressed throughout the visit. This simulated authenticity of the Laughing Cow House, intentionally or not, is intended to create experiences in which visitors recognizes both the objects and the brand as a status of authentic heritage. However, rather than being convincing proof of authenticity, some elements alter visitors' experiences and call into question the brand's ability to preserve original objects and spaces that constitute collective reference points.

Second, by changing objects and spaces from their utilitarian function to more hedonic characteristics, the Laughing Cow House works to be perceived as a symbol of community, like a monument (Riegl, 1903). Through the exhibition, places and objects are changed and even transformed: the aim of the brand is to relieve them of their original utilitarian and technical functions, so that visitors perceive them as anything other than what they are, thus giving them a new aesthetic significance. For this, the museum develops different techniques 
of artification (Heinich et al., 2012). First, the museum aestheticizes the exhibition venue. The museum is located in an old production plant but develops scenographic architecture to enhance the site. According to Aurélie, "the context [of the old cellars] is amazing!” This aestheticization dilutes the original economic function (production activity) of the place. In addition, “while emphasizing a contemporary approach of volumes and spaces where the transparency of glass sits alongside raw wood” (http://www.lamaisondelavachequirit.com), the building's architecture, like many current museum-like structures, is also designed to provide visitors with aesthetic pleasure. Many visitors recognized the aestheticization of the place; for example, Marta noted that she "particularly enjoys the building itself, a mixture of gray and beige, cement and wood," and Aurélie stated that she "cannot help but admire this hall where nature seems to have been invited.” However, even if the place plays an important aesthetic role, the consumer narratives also revealed the difficulty museums experience in finding the formula that can make things aesthetically pleasing to all. In the case of the Laughing Cow House, the coherence of the museum with the identity of the product raises questions, such as that highlighted by Pauline who stated that she is "a little bit lost and ... has the impression of arriving at an aquatic center and a private hospital” or Suzanne who noted that "the building is rather sober and blandly colored, and nothing ...distinguishes it from a contemporary art museum.” These contrasting narratives on the site’s aesthetics suggest the difficulty of building a heritage perspective given its equivocal characteristics and visitors’ subjective evaluations.

Furthermore, the museum re-defines products and objects as art objects. Here, the goal of the artification process is to transform ordinary and everyday goods into extraordinary products. To highlight the aesthetic dimension of objects, the Laughing Cow House uses the typical museum presentation of settings under glass, which leads visitors to look at these objects in a contemplative and distanced way, such as works of art. For example, Magalie said 
that she "admires the first tin box of the Laughing Cow [placed] in a glass case in the middle of the room like a relic, a piece of art,” and Fanette reported that she is amazed by "old black and white ads presented as true treasures.” To accentuate this artification of objects, the museum also designs objects associated with the brand's universe in composition with a clear artistic purpose, as illustrated by the "wall section covered with labels of 'The Laughing Cow' in all languages and with a multitude of graphic charts [that] it is impossible not to notice [as it] is nice, colorful” (Sophie). Finally, the Laughing Cow House tries to demonstrate the brand as a source of artistic inspiration by associating the brand with big names in design. The exhibition displays some commercial objects designed by "the greatest illustrators of the time” as well as "true masterpieces” such as the "advertising designs of Jacques Parnel,” the “original drawing by Benjamin Rabier,” or "these blotters and book covers illustrated by different artists” (exhibition documentation). These objects are considered by Suzanne and Florine as "unique". Visitors learn that "the Laughing Cow is also a modern art brand named 'LVQR' [and that] it really [displays] exhibitions around the brand” (Ines), as exemplified by the temporary exhibition titled "In the milk! When art overflows” geared toward "highlighting the relationship between milk and current practices in contemporary art” (http://www.lamaisondelavachequirit.com).

The identification of heritage technologies moves the Laughing Cow from a purely mercantile registry to the transmission and identity enhancement functions (specific to heritage) and thus legitimizes the brand as a heritage artifact (Figure 1). Note that the heritage technologies the museum uses are interdependent with the brand (Heinich, 2009); they do not work as exclusive criteria but are combined with and reinforce the brand. In addition, one or more of these technologies can be absent without altering the role of the brand museum as a 
place of heritage. Brand museums can represent production spaces of “minor heritage,” in comparison with the ideal museum that aggregates all these technologies.

[Insert Figure 1 about here]

\section{Conclusion}

\subsection{Theoretical implications}

Our research on heritage-making in brand museums contributes to the literature by investigating the heritage experience within retail environments traditionally considered only as particular forms of commercial spaces or communication tools (Danilov, 1992; Hollenbeck et al., 2008; Kozinets et al., 2002; Nissley \& Casey, 2002). However, brand museums do not have only a praxeological goal because they lie at the intersection of the heritage world and the business world. From this perspective, this research stands out from previous work insofar as, even if the heritage process is not obvious (Urde, Greyser, \& Balmer, 2007), our results show that the heritage re-definition of the brand and its recognition as a cultural artifact give it the capacity to renew its value creation (Meisiek \& Barry, 2014; Schiuma, 2011).

Specifically, this research sheds light on how brands can come to be accepted as heritage objects. Note that the brand as a cultural entrepreneur is not the only actor to play a role in legitimizing this heritage approach (Holt, 2002). Brand museums use technologies from the art world to provide intellectual stimulation, aesthetic pleasure, and emotional heritage to visitors (Chen, 2009; Heinich, 2009), and as the results show, visitors perceive these spaces as real museums (Nissley \& Casey, 2002), not only as particular flagship stores. Indeed, visitors recognize the heritage values of brand museums and accept that a brand can present itself as a heritage and cultural artifact. But the brand as a cultural entrepreneur is not the only actor to play a role in heritage legitimization (Holt, 2002). From a dialectical 
perspective, visitors also play a role, by recognizing brand values incorporated within retail environments, thus legitimizing the brand as a heritage artifact. This result can be explained not only by the effectiveness of museum techniques used by these specific flagship stores, but also by the socially constructed nature of heritage that does not exist a priori (Lowenthal, 1998), and by the malleable and complex nature of brands (McCracken, 2005).

Like any museum, brand museums provide a scientific and historical content that helps them to be perceived as a place of knowledge transmission and leads visitors to live an intellectually exciting experience (Falk et al., 2012; Rodner \& Preece, 2015). In parallel, the use of fictional references (tales, legends, anecdotes) helps telling the brand story and emphasizing its sacred nature. Locating in places of origin and exposing undenatured objects, brand museums also display authenticity. By engaging in a process of preservation, thus maintaining the integrity of the relationship with the origin of things (Prentice, 2001), authenticity legitimates the role of the brand as a cultural entrepreneur. Finally, through the re-definition of products and objects as arts objects, brand museums propose a sensory experience for consumers and invite them to consider these objects as artistic spaces.

Furthermore, this research enriches the literature that connects management and the arts by showing that brands can use heritage technologies of the arts for their own purposes. The results suggest that by using heritage technologies, brands can capture the heritage functions of inter-generational memory and community representation, which are universal collective points that individuals use as identity resources (Godelier, 1996). The nature of the value created for the brand through the museum thus no longer fully rests in a market logic. Instead, by legitimizing itself as a heritage artefact, the brand becomes a sacred and inalienable common good. In the museum, the brand appears as an artifact transmitted through inheritance to visitors (Lowenthal, 1998). By treating the brand as a relational resource (inter-generational memory and community representation roles), the company 
moves out of the commercial world; the brand museum places symbolism at the center of the relationship with individuals, which is opposite a commercial space in which the relationship with things controls the individual (Testart, 2001). Thus, through the brand museum and its search for cultural legitimacy, the brand shifts from a market economy logic to a moral economy logic (Weinberg \& Wallendorf, 2012). A moral economy logic can be defined as “a system of transactions which are defined as socially desirable (i.e., moral), because through them social ties are recognized, and balanced social relationships are maintained” (Cheal, 1988, p. 15). The findings suggest that brand museums enhance social relationships between people through the use of heritage technologies and consequently can reinforce the link between consumers and the brand.

\subsection{Managerial implications}

This research has several managerial implications. From a strategic perspective, adopting a heritage ideology allows the brand to gain rare and difficult-to-imitate symbolic benefits in a competitive environment characterized by strong mimicry. The heritagization within brand museums contributes to symbolically re-enchantment the brand by giving it the status of "treasure”, of sacred and inalienable common good (Gauchet, 2005). Thus, brands can build on their heritage to legitimize their inter-generational memory and community representation roles. For example, consider the case of the watchmaker Omega, which offers a museum to show that its products have "recorded some of history's defining moments ... in space, in the oceans' depths, and on the wrists of world leaders [and] explorers” and highlights a heritage of “more than 160 years" on which to develop new products (http://www.omegawatches.com/planet-omega/heritage). Museum spaces, as compelling devices mimicking the art world, offer brands the opportunity to represent, in both material and spatial ways, the inter-generational memory and community representation. 
From a more operational perspective, the number of brand museums continues to grow, indicating that many brands have been able to develop a real brand heritage. However, the costs associated with their development and the resultant closures of unsuccessful museums (e.g., the Amora museum in France, the Jaguar Heritage Museum in Britain, the Museo Storico Alfa Romeo in Italy) indicate that managers must put a great deal of effort in creating a successful heritage process. From this perspective, this study suggests actionable levers to facilitate heritage making. That is, the brand must be based on a set of technologies that help its entry into the heritage registry. Although managers may be tempted to only enhance the old and authentic features of the brand, this research highlights the necessity of using multiple heritage technologies. In addition, this research delineates the operational actions shared by all stakeholders to legitimize the heritage inscription: staging of the exhibition space, scenography around objects, communication in the exhibition, and so on.

\subsection{Limitations and future research directions}

Because of its exploratory nature, this article opens up several avenues of research. First, research should analyze other brands of museums in the agribusiness sector (Mount Gay Rum, Perrier, Coca-Cola, Heineken), as well as other industries, such as automobiles (Mercedes, Peugeot, Ferrari, Volkswagen, BMW) and watches (Omega, Longines, IWC Schaffhausen, Jaeger Lecoultre), to assess the generalization of the results. Research could also extend the heritage corpus to other commercial structures that use cultural features, such as any department stores that host exhibitions of contemporary art (e.g., Bloomingdale's and Macy's in the United States, Harrods in the United Kingdom, Spring Louvre in Paris). The investigation of flagship stores located in places of memory, such as Chanel in Paris, where ready-to-wear and haute couture boutiques are available in the personal apartments of Gabrielle Chanel open to visitors, could also provide useful insights. 
Second, by adopting a heritage framework, this research shows that brands can legitimize themselves as heritage artifacts through the roles and technologies deployed in their museums. Furthermore, this legitimacy issue is supported by a differentiating issue from a business perspective (Hollenbeck et al., 2008). However, as Chaney and Marshall (2013) find in the case of music festivals, the search for legitimacy of cultural organizations can contradict commercial objectives pursued in parallel. It may therefore be appropriate to explore the representations associated by managers with brand museums to understand, from a strategic perspective, how they articulate cultural objectives (search for legitimacy) and business goals (search of differentiation).

Finally, although the findings show that visitors can accept brands as heritage artifacts, they do not explain the impact of consumers' visits on their relationship with the brand. As do Dolbec and Chebat (2013), who measure the impact of flagship stores on consumers' attachment to and attitudes toward the brand, further research could examine the impact of visits to a brand museum on consumers' perceptions of the brand. Since this research has highlighted the unusual character conferred by the museum to the brand, measuring the impact of a brand's heritage on the consumer-brand relationship would be worthwhile. 


\section{Figure 1}

The inter-generational memory and community representation role of brands in brand museums.

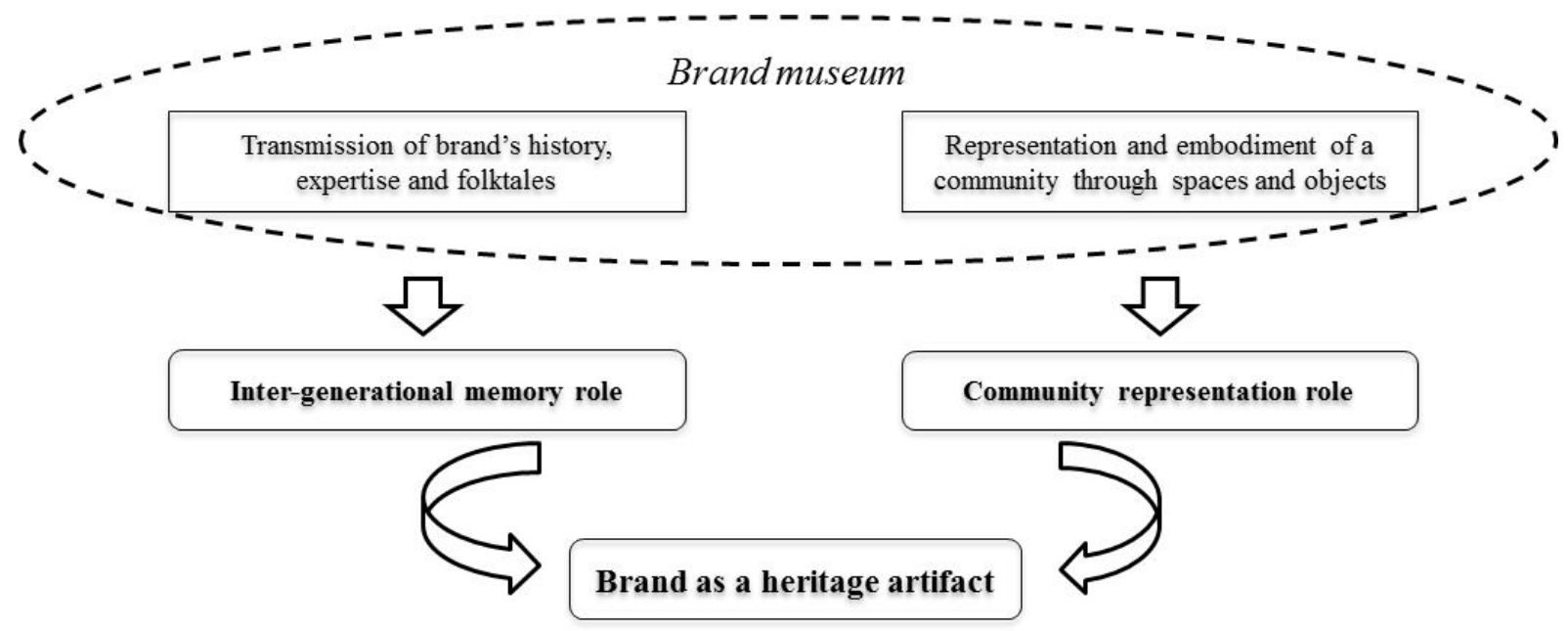


Table 1

Informant demographics.

\begin{tabular}{|c|c|c|c|}
\hline Informant (gender) & Occupation & Region & $\begin{array}{c}\text { Introspection } \\
\text { (number of } \\
\text { pages) }\end{array}$ \\
\hline Morgane (F) & Project manager & Rhône-Alpes & 7 \\
\hline Caroline (F) & Socio-cultural organizer & Bourgogne & 3 \\
\hline Chloé (F) & Communication assistant & Bourgogne & 6 \\
\hline Aurélie (F) & Project manager & Bourgogne & 4 \\
\hline Suzanne (F) & Sales consultant & Rhône-Alpes & 11 \\
\hline Marta (F) & Reception officer & Languedoc Roussillon & 6 \\
\hline Magalie (F) & Engineer & Bourgogne & 4 \\
\hline Fanette (F) & Development officer & Bourgogne & 6 \\
\hline Elise $(\mathrm{F})$ & Sales assistant & Franche Comté & 4 \\
\hline Sophie (F) & Graduate student & Rhône-Alpes & 4 \\
\hline Inès (F) & Research manager & Bourgogne & 8 \\
\hline Noémie (F) & Customer service adviser & Ile de France & 5 \\
\hline Anne-Lucie (F) & Communication assistant & Pays de la Loire & 6 \\
\hline Florine $(\mathrm{F})$ & Assistant project manager & Alsace & 11 \\
\hline Mathilde (F) & Graduate student & Provence-Alpes-Côte d'Azur & 6 \\
\hline Laura (F) & Librarian & Bourgogne & 5 \\
\hline Julie (F) & Real estate agent & Rhône Alpes & 3 \\
\hline Maud (F) & Event manager & Bourgogne & 5 \\
\hline Pauline (F) & Marketing assistant & Auvergne & 4 \\
\hline Aurore (F) & Shop manager & Centre-Val de Loire & 2 \\
\hline Marine (F) & Quality manager & Rhône-Alpes & 4 \\
\hline Pascal (M) & School monitor & Bretagne & 4 \\
\hline Henry (M) & Communication director & Rhône-Alpes & 4 \\
\hline
\end{tabular}




\section{References}

Adorno, T., \& Horkheimer, M. (2007). The culture industry: Enlightenment as mass deception. In S. Redmond \& S. Holmes (Eds.), Stardom and celebrity: A reader (pp. 34-43). London: Sage.

Arnould, E.-J., \& Wallendorf, M. (1994). Market-oriented ethnography: interpretation building and marketing strategy formulation. Journal of Marketing Research, 31(4), 484-504.

Becker, H. S. (1982). Art worlds. Berkeley: University of California Press.

Benjamin, W. (1968). Illuminations: Essays and reflections. Berlin: Schocken Books.

Brellochs, M., \& Schrat, H. (2005). Product \& vision: An experimental set-up between art and business. Berlin: Kulturverlag Kadmos.

Brown, S., Kozinets, R. V., \& Sherry Jr, J. F. (2003). Teaching old brands new tricks: Retro branding and the revival of brand meaning. Journal of Marketing, 67(3), 19-33.

Burghausen, M., \& Balmer, J. M. (2014). Corporate heritage identity management and the multi-modal implementation of a corporate heritage identity. Journal of Business Research, 67(11), 2311-2323.

Byrom, J., \& Lehman, K. (2009). Coopers Brewery: Heritage and innovation within a family firm. Marketing Intelligence \& Planning, 27(4), 516-523.

Chaney, D., \& Marshall, R. (2013). Social legitimacy versus distinctiveness: Mapping the place of consumers in the mental representations of managers in an institutionalized environment. Journal of Business Research, 66(9), 1550-1558.

Cheal, D. (1988), The gift economy. London: Routledge.

Chen, Y. (2009). Possession and access: Consumer desires and value perceptions regarding contemporary art collection and exhibit visits. Journal of Consumer Research, 35(6), 925-940. 
Chong, D. (2013). Institutions trust institutions critiques by artists of the BP/Tate partnership. Journal of Macromarketing, 33(2), 104-116.

Cleere, H. (2001). The uneasy bedfellows: Universality and cultural heritage. In R. Layton, P. Stone, \& J. Thomas (Eds.), Destruction and conservation of cultural property (pp. 2229). London: Routledge.

Danilov, V. J. (1992). A planning guide for corporate museums, galleries, and visitor centers. Westport: Greenwood Publishing Group.

Davison, P. (2005). Museums and the re-shaping of memory. In G. Corsane (Ed.) Heritage, museums and galleries: An introductory reader (pp. 202-214). Abingdon: Routledge.

Di Giovine, M. A. (2008). The heritage-scape: UNESCO, world heritage, and tourism. Lanham: Lexington Books.

Dicks, B. (2000). Heritage, place and community. Wales: University of Wales Press.

Dion, D., \& Arnould, E. J. (2011). Retail luxury strategy: Assembling charisma through art and magic. Journal of Retailing, 87(4), 502-520.

Dolbec, P. Y., \& Chebat, J. C. (2013). The impact of a flagship vs. a brand store on brand attitude, brand attachment and brand equity. Journal of Retailing, 89(4), 460-466.

Eco, U. (1986). Travels in hyperreality: Essays. San Diego: Harcourt, Brace \& Company. Eliade, M. (1954). The myth of the eternal return: Cosmos and history. New York: Pantheon.

Falk, J. H., Ballantyne, R., Packer, J., \& Benckendorff, P. (2012). Travel and learning: A neglected tourism research area. Annals of Tourism Research, 39(2), 908-927.

Gauchet, M. (2005), Le Désenchantement du monde. Une histoire politique de la religion. Paris: Gallimard.

Godelier, M. (1996), L’énigme du don. Paris: Arthème/Fayard.

Gould, S. J. (2006). Comparing, not confirming personal introspection: A comment on Woodside. Psychology \& Marketing, 23(3), 253-256. 
Goulding, C. (2000). The commodification of the past, postmodern pastiche, and the search for authentic experiences at contemporary heritage attractions. European Journal of Marketing, 34(7), 835-853.

Goulding, C. (2005), Grounded theory, ethnography and phenomenology: A comparative analysis strategies for marketing research. European Journal of Marketing, 39(3-4), 294-308.

Grayson, K., \& Martinec, R. (2004). Consumer perceptions of iconicity and indexicality and their influence on assessments of authentic market offerings. Journal of Consumer Research, 31(2), 296-312.

Grimwade, G., \& Carter, B. (2000). Managing small heritage sites with interpretation and community involvement. International Journal of Heritage Studies, 6(1), 33-48.

Heinich, N. (2009), La fabrique du patrimoine: “De la cathédrale à la petite cuillère.” Paris, Éditions de la Maison des sciences de l'homme.

Heinich, N., Shapiro, R., Brunet, F., Chaudron, M., Crane, D., Fraenkel, B, Jones, G. Liebaut, M. Melot, M., Moulinié, V. (2012). De l'artification: enquêtes sur le passage à l'art. Paris : EHESS.

Hollenbeck, C. R., Peters, C., \& Zinkhan, G. M. (2008). Retail spectacles and brand meaning: Insights from a brand museum case study. Journal of Retailing, 84(3), 334-353.

Holt, D. B. (2002). Why do brands cause trouble? A dialectical theory of consumer culture and branding. Journal of Consumer Research, 29(1), 70-90.

Holt, D. B. (2004). How brands become icons: The principles of cultural branding. Boston: Harvard Business Press.

Joy, A., Wang, J. J., Chan, T. S., Sherry, J. F., and Cui, G. (2014). M(Art) worlds: Consumer perceptions of how luxury brand stores become art institutions. Journal of Retailing, 90(3), 347-364. 
Kozinets, R. V., Sherry Jr, J. F., DeBerry-Spence, B., Duhachek, A., Nuttavuthisi,t K., \& Storm, D. (2002). Themed flagship brand stores in the new millennium: Theory, practice, prospects. Journal of Retailing, 78(1), 17-29.

Lowenthal, D. (1998). The heritage crusade and the spoils of history. New York: Cambridge University Press.

McCracken, G. D. (2005). Culture and consumption II: Markets, meaning, and brand management. Bloomington: Indiana University Press.

Meisiek, S., \& Barry, D. (2014). The science of making management an art. Scandinavian Journal of Management, 30(1), 134-141.

Nissley, N., \& Casey, A. (2002). The politics of the exhibition: Viewing corporate museums through the paradigmatic lens of organizational memory. British Journal of Management, 13(2), 35-45.

Oldenburg, R. (2001). Celebrating the third place: Inspiring stories about the "great good places" at the heart of our communities. New York: Marlowe \& Co.

Prentice, R. (2001). Experiential cultural tourism: Museums and the marketing of the new romanticism of evoked authenticity. Museum Management and Curatorship, 19(1), 526.

Riegl, A. (1903). Le culte moderne des monuments. Paris: L'Harmattan.

Ritzer, G. (2005). The McDonaldization of society. Thousand Oaks: Pine Forge Press.

Rodner, V. L., \& Preece, C. (2015). Tainted museums: “selling out” cultural institutions. International Journal of Nonprofit and Voluntary Sector Marketing, 20(2), 149-169.

Rose, G. M., Merchant, A., Orth, U. R., \& Horstmann, F. (2016). Emphasizing brand heritage: Does it work? And how?. Journal of Business Research, 69(2), 936-943.

Rowlands, M., \& De Jong, F. (2007). Reclaiming heritage: alternative imaginaries of memory in West Africa. Walnut Creek: Left Coast Press. 
Schiuma, G. (2011). The value of arts for business. New York: Cambridge University Press. Schroeder, J. E. (2006). Aesthetics awry: The painter of light ${ }^{\mathrm{TM}}$ and the commodification of artistic values. Consumption, Markets and Culture, 9(02), 87-99.

Smith, L. (2006). Uses of heritage. Abingdon: Routledge.

Spiggle, S. (1994). Analysis and interpretation of qualitative data in consumer research. Journal of Consumer Research, 21(3), 491-503.

Takhar-Lail, A., \& Chitakunye, P. (2015). Reflexive introspection: Methodological insights from four ethnographic studies. Journal of Business Research, 68(11), 2383-2394.

Tellström, R., Gustafsson, I. B., \& Mossberg, L. (2006). Consuming heritage: The use of local food culture in branding. Place Branding, 2(2), 130-143.

Testart, A. (2001). Echange marchand, échange non marchand. Revue Française de Sociologie, 42, 719-748.

Thompson, C. J. (1997). Interpreting consumers: A hermeneutical framework for deriving marketing insights from the texts of consumers' consumption stories. Journal of Marketing Research, 34, 438-455.

Thompson C. J. (2006). The McDonaldization of enchantment and consumers practices of reenchantment: A dialectic view of transformative consumption. In C. Pechmann \& L. Price (Eds.), Advances in consumer research (Vol. 33, pp. 352-354). Duluth: Association for Consumer Research.

Urde, M., Greyser, S. A., \& Balmer, J. M. (2007). Corporate brands with a heritage. Journal of Brand Management, 15(1), 4-19.

Wallendorf, M., \& Brucks, M. (1993). Introspection in consumer research: Implementation and implications. Journal of Consumer Research, 20(3), 339-359. 
Weinberger, M. F., \& Wallendorf, M. (2012). Intracommunity gifting at the intersection of contemporary moral and market economies. Journal of Consumer Research, 39(1), 74-92.

Wilson, T. M. (2006). Food, drink and identity in Europe: Consumption and the construction of local, national and cosmopolitan culture. European Studies: A Journal of European Culture, History and Politics, 22(1), 11-29.

Yin, R. K. (2013). Case study research: Design and methods. Thousand Oaks: Sage. 